\title{
Stable Carbon Isotope Fractionation during Bacterial Acetylene Fermentation: Potential for Life Detection in Hydrocarbon-Rich Volatiles of Icy Planet(oid)s
}

\author{
Laurence G. Miller, Shaun M. Baesman, and Ronald S. Oremland
}

\begin{abstract}
We report the first study of stable carbon isotope fractionation during microbial fermentation of acetylene $\left(\mathrm{C}_{2} \mathrm{H}_{2}\right)$ in sediments, sediment enrichments, and bacterial cultures. Kinetic isotope effects (KIEs) averaged $3.7 \pm 0.5 \%$ for slurries prepared with sediment collected at an intertidal mudflat in San Francisco Bay and $2.7 \pm 0.2 \%$ for a pure culture of Pelobacter sp. isolated from these sediments. A similar KIE of $1.8 \pm 0.7 \%$ was obtained for methanogenic enrichments derived from sediment collected at freshwater Searsville Lake, California. However, $\mathrm{C}_{2} \mathrm{H}_{2}$ uptake by a highly enriched mixed culture (strain SV7) obtained from Searsville Lake sediments resulted in a larger KIE of $9.0 \pm 0.7 \%$. These are modest KIEs when compared with fractionation observed during oxidation of $\mathrm{C}_{1}$ compounds such as methane and methyl halides but are comparable to results obtained with other $\mathrm{C}_{2}$ compounds. These observations may be useful in distinguishing biologically active processes operating at distant locales in the Solar System where $\mathrm{C}_{2} \mathrm{H}_{2}$ is present. These locales include the surface of Saturn's largest moon Titan and the vaporous water- and hydrocarbon-rich jets emanating from Enceladus. Key Words: AcetyleneFermentation-Isotope fractionation-Enceladus-Life detection. Astrobiology 15, 977-986.
\end{abstract}

\section{Introduction}

A CETYLENE $\left(\mathrm{C}_{2} \mathrm{H}_{2}\right)$ is formed in planetary atmospheres primarily by photochemical conversion of methane (Kasting et al., 1983; Zahnle, 1986). Methane $\left(\mathrm{CH}_{4}\right)$ and hence acetylene were abundant in the anoxic atmosphere of early Earth (Kasting, 2005). Both gases have been identified in comets (Brooke et al., 1996; Mumma et al., 2005), thereby adding organic material to early Earth (Chyba et al., 1990) and throughout the Solar System. Today, terrestrial tropospheric concentrations of $\mathrm{C}_{2} \mathrm{H}_{2}$ are generally less than $0.1 \mathrm{ppbv}$, a level which is mostly supported by anthropogenic leakage. Minor amounts of $\mathrm{C}_{2} \mathrm{H}_{2}$ are produced during biomass burning (Andrea and Merlet, 2001) and by methanogenic attack of halogenated hydrocarbons (Belay and Daniels, 1987). Much higher $\mathrm{C}_{2} \mathrm{H}_{2}$ concentrations (ppmv and higher levels) are found within the atmospheres of a number of jovian-type planets and satellites in our solar system (Macy, 1980; Noll et al., 1986; Waite et al., 2007; Oremland and Voytek, 2008). For example, Titan's upper atmosphere contains abundant $\mathrm{C}_{2} \mathrm{H}_{2}$ (Shemansky et al., 2005), the condensation and sedimentation of which (Schulze-Makuch and Grinspoon, 2005) leads to concentrations up to $1 \%$ in the liquid hydrocarbon lakes on its surface (Cordier et al., 2009). The vaporous plumes emanating from the south polar region of Enceladus, Saturn's sixth largest moon, may contain $\mathrm{C}_{2} \mathrm{H}_{2}$ along with other organic compounds, water, and salts (Waite et al., 2006; Postberg et al., 2011). Matson et al. (2007) proposed that $\mathrm{C}_{2} \mathrm{H}_{2}$ originates within Enceladus by thermal processes, with a liquid water body below the icy surface in contact with a hot silicate core. External sources of $\mathrm{C}_{2} \mathrm{H}_{2}$ have also been suggested (Waite et al., 2009; McKay et al., 2012).

There are few chemical reactions that consume $\mathrm{C}_{2} \mathrm{H}_{2}$. Acetylene is used commercially as a feedstock for the production of other organic compounds via catalytic cyclization (Reppe et al., 1969). Removal of traces of $\mathrm{C}_{2} \mathrm{H}_{2}$ from the product stream is performed industrially at elevated temperatures using palladium catalysts often containing other metals (Studt et al., 2008). A more familiar process, combustion, requires a strong oxidant such as $\mathrm{O}_{2}$ or $\mathrm{N}_{2} \mathrm{O}$ and an ignition source. Pyrolysis of $\mathrm{C}_{2} \mathrm{H}_{2}$ has also been shown to

U.S. Geological Survey, Menlo Park, California.

(c) The Author(s) 2015; Published by Mary Ann Liebert, Inc. This Open Access article is distributed under the terms of the Creative Commons License (http://creativecommons.org/licenses/by/4.0), which permits unrestricted use, distribution, and reproduction in any medium, provided the original work is properly credited. 
occur in anoxic aqueous solutions under intense ultrasound irradiation (Hart et al., 1990). Note that the above chemical reactions all require elevated concentrations of $\mathrm{C}_{2} \mathrm{H}_{2}$ or large expenditures of energy in order to proceed. Reaction with hydroxyl radical has been demonstrated (Breen and Glass, 1971); however, this process is unlikely to be important in our troposphere where $\mathrm{C}_{2} \mathrm{H}_{2}$ mixing ratios are low.

Biological processes consume $\mathrm{C}_{2} \mathrm{H}_{2}$ over a range of concentrations and environmental conditions. Aerobic oxidation of $\mathrm{C}_{2} \mathrm{H}_{2}$ by the bacterium Nocardia rhodochrous (now called Rhodococcus rhodochrous) was documented by Kanner and Bartha (1979) followed by the observation of anaerobic $\mathrm{C}_{2} \mathrm{H}_{2}$ fermentation when using cell-free extracts of Rhodococcus A1 (de Bont and Peck, 1980). Anaerobic oxidation of $\mathrm{C}_{2} \mathrm{H}_{2}$ in enrichment cultures derived from estuarine sediments (Culbertson et al., 1981) resulted in the production of $\mathrm{CO}_{2}$, and a hypothesized role of $\mathrm{C}_{2} \mathrm{H}_{2}$ as a potential source of carbon and energy for primordial and extraterrestrial food chains was suggested (Culbertson et al., 1988; Oremland and Voytek, 2008). McKay and Smith (2005) calculated that hydrogenation of $\mathrm{C}_{2} \mathrm{H}_{2}$ to $\mathrm{CH}_{4}$ could support alien methanogenic life on the surface of Titan at $90 \mathrm{~K}$.

Fermentation of $\mathrm{C}_{2} \mathrm{H}_{2}$ has been well studied by using the model organism Pelobacter acetylenicus (Schink, 1985) from which the acetylene hydratase enzyme $(\mathrm{AH})$ was isolated and purified (Rosner and Schink, 1995; Meckenstock et al., 1999; Seiffert et al., 2007). This enzyme is uniquely specific for acetylene and will not react with other compounds (tenBrink et al., 2011). No cross-reactivity was found between antibodies raised against $P$. acetylenicus and cell-free extracts of aerobic acetylene consumers (Rosner et al., 1997), suggesting that aerobic and anaerobic forms of $\mathrm{AH}$ are structurally different.

Miller et al. (2013) conducted a survey of AH activity in likely anoxic environments and in addition developed a genetic method of AH detection based on gene amplification from extracted DNA using a degenerate primer derived from $P$. acetylenicus. Few $(21 \%)$ of the environments tested showed AH activity, while fewer still (10\%) tested positive for the AH gene. They suggested insufficient degeneracy in their primer design as an explanation for this observation but offered the possibility that other metabolic pathways could be operative in those cases where $\mathrm{AH}$ activity was present without detection of the $\mathrm{AH}$ gene. They highlighted two cultures as examples of (1) organisms that fermented $\mathrm{C}_{2} \mathrm{H}_{2}$ and contained the $\mathrm{AH}$ gene (SFB93, from San Francisco Bay) and (2) organisms that fermented $\mathrm{C}_{2} \mathrm{H}_{2}$ but lacked the $\mathrm{AH}$ gene (SV7, from Searsville Lake, CA). These two cultures, sediments, and sediment enrichments from the two environments are the subject of further examination presented in this study.

Patterns of stable carbon isotope fractionation have long been used to distinguish biological processes from purely physical/chemical processes involving carbon compounds. Examples include numerous studies on the provenance of natural hydrocarbons in Earth's crust and sediments (Rosenfeld and Silverman, 1959; Schoell, 1980, 1988; Pohlman et al., 2009). The two principle biochemical pathways of $\mathrm{CH}_{4}$ formation (fermentation and $\mathrm{CO}_{2}$ reduction) result in different biological fractionation factors $\left(\alpha=\kappa_{12} / \kappa_{13}\right)$, and the gas produced can be further distinguished from thermogenic methane by using stable isotopes alone (Whiticar et al., 1986). Consumption of $\mathrm{CH}_{4}$ results in smaller kinetic isotope effects $(\mathrm{KIE}=\varepsilon$ or $[\alpha-1] \times 1000)$ for abiotic reaction with $\mathrm{OH}$ radicals in the troposphere (Rust and Stephens, 1980; Cantrell et al., 1990) than for microbial oxidation in oxic or anoxic aquatic environments (Whiticar, 1999; Templeton et al., 2006; Kinnaman et al., 2007). Similarly, the carbon KIE for chemical uptake of methyl bromide was significantly lower than the KIE for microbial oxidation in pure cultures, enrichment cultures, and in agricultural field fumigation experiments and soil microcosms (Miller et al., 2001, 2004; Bill et al., 2002). Conversely, larger KIEs were observed for abiotic transformation of the chlorinated ethene TCE (Bill et al., 2001; Slater et al., 2002) than were achieved during microbial reductive dehalogenation of this compound (Bloom et al., 2000; Liang et al., 2007). In addition, abiogenic hydrocarbon production by various mechanisms may result in isotopically depleted products (Sherwood Lollar et al., 2008) giving the appearance of biogenic fractionation. Thus, disparate stable isotope fractionation patterns must be evaluated in concert with additional information to distinguish abiotic from biogenic pathways of production or consumption.

In addition to their use in inferring the pathway of degradation, stable carbon isotopes are used to determine the degree of organic contaminant transformation during degradation by observing the relative enrichment of ${ }^{13} \mathrm{C}$ in reactive substrates (Meckenstock et al., 2004; Elsner et al., 2005; Hofstetter et al., 2008). Using this approach, the amount of chlorinated ethene biodegradation via various pathways may be distinguished by using stable isotope fractionation patterns coupled with reactive transport modeling. The assessment of biological and chemical KIEs is an important first step in applying patterns of stable carbon isotope fractionation to distinguish biological from nonbiological processes or to discern the degree of transformation of carbon compounds. In the case of $\mathrm{C}_{2} \mathrm{H}_{2}$, there are few important chemical reactions to consider; hence, we investigated biological KIEs. This study reports the first documented stable carbon isotope fractionation of $\mathrm{C}_{2} \mathrm{H}_{2}$ during fermentation by estuarine sediments, sediment enrichments derived from freshwater mud, and pure cultures obtained from estuarine sediments.

\section{Materials and Methods}

\subsection{Sediments and enrichments}

Estuarine sediments were collected at low tide from the surface of an intertidal mudflat in San Francisco Bay (Culbertson et al., 1981; Miller et al., 2013). Sediment slurries were prepared under flowing $\mathrm{N}_{2}$ by mixing sediment with artificial mineral salts media (ABW; Culbertson et al., 1981) in a large beaker in a ratio of 1 part sediment to 5 parts ABW. Freshwater lake sediments were collected by Ekman Grab from Searsville Lake, Stanford, California, at a water depth of $5 \mathrm{~m}$. Sediment slurries were prepared similarly using freshwater media (SeFr1 and SeFr2; Miller et al., 2013).

Acetylene fermenters were enriched from incubated sediment slurries of San Francisco Bay and Searsville Lake that demonstrated $\mathrm{C}_{2} \mathrm{H}_{2}$ consumption (Table 1). A complete description of the enrichment and cultivation of strains SFB93 and SV7 was presented by Miller et al. (2013). Amplification 
Table 1. Sediments, Sediment Enrichments, and Cultures Derived from Sediments Representing Various Stages of Purification

\begin{tabular}{|c|c|c|c|c|}
\hline Sample & Date collected & Location & Steps taken toward purification & $\begin{array}{l}\text { Number of } \\
\text { organisms }\end{array}$ \\
\hline SFB5 & $12 / 19 / 07$ & $\begin{array}{l}\text { San Francisco Bay } \\
\text { Palo Alto, CA } \\
\text { N } 37^{\circ} 27^{\prime} 28.13^{\prime \prime} \\
\text { W } 122^{\circ} 06^{\prime} 03.73^{\prime \prime}\end{array}$ & None; this is the original slurry in $\mathrm{ABW}^{\mathrm{a}}$. & Not tested \\
\hline SFB93 & $12 / 19 / 07$ & $\begin{array}{l}\text { San Francisco Bay } \\
\text { Palo Alto, CA } \\
\text { N } 37^{\circ} 27^{\prime} 28.13^{\prime \prime} \\
\text { W } 122^{\circ} 06^{\prime} 03.73^{\prime \prime}\end{array}$ & $\begin{array}{l}9 \text { transfers from original slurry in } \mathrm{ABW}+1.6 \mathrm{~m} M \\
\text { cysteine-HCl. Transfer to agar plate. Pick individual } \\
\text { colony from agar and grow on } \mathrm{ABW}+\text { vitamins and } \\
\text { trace elements. }\end{array}$ & 1 \\
\hline SVM & $2 / 22 / 12$ & $\begin{array}{l}\text { Searsville Lake } \\
\text { Stanford, CA } \\
\text { N } 37^{\circ} 24^{\prime} 26.63^{\prime \prime} \\
\text { W } 122^{\circ} 14^{\prime} 16.98^{\prime \prime}\end{array}$ & 4 transfers from original slurry in $\mathrm{SeFr} 2^{\mathrm{b}}$ & Not tested \\
\hline SV7 & $6 / 24 / 08$ & $\begin{array}{l}\text { Searsville Lake } \\
\text { Stanford, CA } \\
\text { N } 37^{\circ} 24^{\prime} 26.63^{\prime \prime} \\
\text { W } 122^{\circ} 14^{\prime} 16.98^{\prime \prime}\end{array}$ & $\begin{array}{l}9 \text { transfers from original slurry in } \mathrm{SeFr} 1^{\mathrm{c}}+1 \mathrm{~m} M \text { sulfide. } \\
\text { Final transfer to SeFre } 2^{\mathrm{b}}+1 \mathrm{~m} M \text { sulfide. Transfer to } \\
\text { agar plate. Pick individual colony from agar and } \\
\text { perform dilution to extinction in SeFr2. Choose } \mathrm{e}^{5} \text { tube } \\
\text { and grow on } \mathrm{SeFr} 2+\text { vitamins and trace elements. }\end{array}$ & $\geq 6$ \\
\hline
\end{tabular}

\footnotetext{
${ }^{\mathrm{a}} \mathrm{ABW}=$ Artificial Bay Water media.

${ }^{\mathrm{b}} \mathrm{SeFr} 2=$ Fresh Water media lacking $\mathrm{SO}_{4}{ }^{2-}$

${ }^{\mathrm{c}} \mathrm{SeFr} 1=$ Fresh Water media with $2.2 \mathrm{mM} \mathrm{SO}_{4}^{2-}$.
}

and sequencing of the 16S rRNA gene revealed SFB93 to be composed of a single clone aligning within the pelobacter clade and having $96 \%$ sequence similarity to Pelobacter acetylenicus (GenBank accession number JQ085863). By contrast, SV7 defied purification into a single isolate. At the time of publication (Miller et al., 2013), SV7 consisted of several (perhaps six) species of bacteria, including actinobacteria and a sulfurospirillum-like organism, but no pelobacters.

Acetylene used throughout this study was generated by the reaction of calcium carbide with water:

$$
\mathrm{CaC}_{2}+2 \mathrm{H}_{2} \mathrm{O} \rightarrow \mathrm{C}_{2} \mathrm{H}_{2}+\mathrm{Ca}(\mathrm{OH})_{2}
$$

Two liters of $\mathrm{C}_{2} \mathrm{H}_{2}$ were purified by cryogenic transfer using liquid nitrogen through water vapor traps at $-87^{\circ} \mathrm{C}$ in a vacuum line, followed by pumping of noncondensable gas. The purified gas was frozen into several serum bottles for use in subsequent experiments. Acetylene introduced into the headspace of tubes or serum bottles was distributed between liquid and headspace volumes according to Henry's law such that about two-thirds of the gas was dissolved and one-third remained in the headspace after $20 \mathrm{~min}$ equilibration. Incubations began with initial headspace concentrations of $90-240 \mu \mathrm{mol} \mathrm{L}{ }^{-1} \mathrm{C}_{2} \mathrm{H}_{2}$.

\subsection{Incubations}

San Francisco Bay sediment slurries (SFB5; $20 \mathrm{~mL}$ ) were dispensed under flowing $\mathrm{N}_{2}$ to serum bottles $(160 \mathrm{~mL}$ total volume) containing $10 \mathrm{~mL} \mathrm{ABW}$ and stoppered before flushing with oxygen-free $\mathrm{N}_{2}$ for an additional $5 \mathrm{~min}$. A single heat-killed control was prepared by autoclaving $\left(121^{\circ} \mathrm{C}, 203 \mathrm{kPa}\right.$ for $\left.1 \mathrm{~h}\right)$. Incubations were started by addition of $0.5 \mathrm{~mL} \mathrm{C}_{2} \mathrm{H}_{2}$ to the headspace and were allowed to equilibrate for $20 \mathrm{~min}$ before initial headspace samples were collected. Slurries were incubated in the dark at $28^{\circ} \mathrm{C}$ with rotary shaking at $120 \mathrm{rpm}$. Subsequent headspace samples were collected approximately hourly for $7 \mathrm{~h}$.

Cultures of acetylene fermenters were grown on mineral salts media with added SL10 trace elements (Widdel et al., 1983) and vitamins (Oremland et al., 1994) with cysteine$\mathrm{HCl}$ (SFB93) or $\mathrm{Na}_{2} \mathrm{~S}$ (SV7) as reducing agent (Table 1). Strain SFB93 was harvested in late exponential phase for incubation either in growth mode or as a washed-cell suspension. Manipulation of cultures took place in an anaerobic chamber (Type A, Coy Laboratory Products, Ann Arbor, MI) under a mixture of $5 \% \mathrm{H}_{2}, 5 \% \mathrm{CO}_{2}$, and $90 \% \mathrm{~N}_{2}$. For growth experiments, SFB93 $(10 \mathrm{~mL})$ was transferred directly to Balch tubes $(37 \mathrm{~mL})$, stoppered, and flushed with oxygen-free $\mathrm{N}_{2}$ for $5 \mathrm{~min}$. Cell densities were determined by direct cell counting using acridine orange epifluorescence microscopy (Hobbie et al., 1977). Initial cell density was $3.0 \times 10^{7} \mathrm{cells} \mathrm{cm}^{-3}$. Final cell density was not determined. For washed-cell experiments, cells were centrifuged $(7000 \mathrm{~g})$ and washed twice and then resuspended in a mineral salts medium that lacked trace metals and vitamins before transferring $30 \mathrm{~mL}$ to $160 \mathrm{~mL}$ serum bottles and flushing with $\mathrm{N}_{2}$. Initial cell density was $1.3 \times 10^{8}$ cells $\mathrm{cm}^{-3}$. Final cell density was not determined. Triplicate experimental tubes and a single heat-killed control were prepared for each condition. Incubations were started by addition of $0.2 \mathrm{~mL} \mathrm{C}_{2} \mathrm{H}_{2}$ to the headspace of tubes and $0.5-1.0 \mathrm{~mL} \mathrm{C}_{2} \mathrm{H}_{2}$ to the headspace of serum bottles. Incubations were conducted in the dark at $28^{\circ} \mathrm{C}$ and $14^{\circ} \mathrm{C}$ with rotary shaking at $120 \mathrm{rpm}$.

Sediment enrichments were evaluated at various points along the pathway to purification. Searsville Lake sediment collected from the same site as SV7 but on a different sampling date was transferred four times from slurry using 
SeFr2 media. This enrichment (SVM) produced up to 7 mmol L ${ }^{-1}$ methane during $\mathrm{C}_{2} \mathrm{H}_{2}$ consumption. The mixed culture was grown to late exponential phase, and $10 \mathrm{~mL}$ was transferred to three serum bottles $(160 \mathrm{~mL})$ containing $20 \mathrm{~mL} \mathrm{SeFr} 2$ for incubation at $28^{\circ} \mathrm{C}$ as above with addition of $0.5 \mathrm{~mL} \mathrm{C}_{2} \mathrm{H}_{2}$ to start.

Enrichment strain SV7 was harvested during exponential phase for incubation in growth mode. A $10 \mathrm{~mL}$ aliquot of the growing culture was transferred in the anaerobic chamber into $160 \mathrm{~mL}$ serum bottles containing $20 \mathrm{~mL}$ medium (Rosner et al., 1997). Bottles were stoppered and flushed with oxygenfree $\mathrm{N}_{2}$ prior to the start of incubations. Initial cell densities ranged from $1.8 \times 10^{7}$ to $4.8 \times 10^{7}$ cells $\mathrm{cm}^{-3}$. Incubations were started by addition of $0.5 \mathrm{~mL} \mathrm{C}_{2} \mathrm{H}_{2}$ to the headspace of bottles. Six replicate experimental bottles and one heat-killed control were incubated in the dark with shaking at $28^{\circ} \mathrm{C}$.

\subsection{Analytical}

Measurements of headspace concentration and stable carbon isotopic composition were made separately and simultaneously at each time point to determine the KIE due to acetylene fermentation. Headspace $\mathrm{C}_{2} \mathrm{H}_{2}$ concentrations were quantified by flame ionization gas chromatography (Miller et al., 1997, 2013). Precision of FID analyses was $\pm 3 \%$ of the reported concentration. The concentration of $\mathrm{C}_{2} \mathrm{H}_{2}$ in each bottle was determined by comparison with standards prepared by dilution of $100 \%$ purified $\mathrm{C}_{2} \mathrm{H}_{2}$.

The stable carbon isotopic composition ( $\delta^{13} \mathrm{C}$ vs. VPDB) was determined by isotope-ratio-monitoring gas chromatographycombustion-mass spectrometry (GC-C-IRMS) using a HP 5890 gas chromatograph (Agilent Technologies, Santa Clara, CA) fitted with a GS-CARBONPLOT capillary column $(30 \mathrm{~m} \times 0.32 \mathrm{~mm} \times 3.0 \mu \mathrm{m}$ film thickness; J\&W Scientific, Agilent Technologies, Santa Clara, CA) connected to an Elementar IsoPrime mass spectrometer through a $\mathrm{CuO} / \mathrm{NiO}$ combustion interface and a Nafion (Perma Pure, Toms River, NJ) water trap (Kalin et al., 2001; Bill et al., 2002). The $\mathrm{CO}_{2}$ monitoring gas measured with each analysis was calibrated against a range of international standards, including NBS-19 and NBS-22 (1.95\% and $-30.0 \%$ vs. VPDB, respectively).

Precision of the measured $\delta^{13} \mathrm{C}$ values of acetylene was $\pm 0.5 \%$. Accuracy was evaluated by independently measuring the acetylene reference gas with elemental analyzerisotope ratio mass spectrometry (EA-IRMS), the spectrometer configured such that a Carlo Erba NA 1500 elemental analyzer was connected to an Elementar Optima mass spectrometer. The $\delta^{13} \mathrm{C}$ values of $\mathrm{C}_{2} \mathrm{H}_{2}$ were corrected to an EDTA working standard calibrated against a range of international standards, including NBS-19 and NBS-23 $(-35.5 \%$ vs. VPDB). The $\delta^{13} \mathrm{C}$ values for the acetylene reference gas analyzed by GC-C-IRMS were consistently depleted in ${ }^{13} \mathrm{C}$ $(1.7 \pm 0.6 \%$ ) compared with the EA-IRMS values. No correction for this discrepancy was made.

Kinetic isotope effects were calculated from the slope of the regression of the logarithm of the fraction of reactant acetylene remaining $\left[-\ln \left(\mathrm{C} / \mathrm{C}_{0}\right)\right]$ against the $\delta^{13} \mathrm{C}$ value at the corresponding time point. Concentration and isotopic composition data from at least three replicates for each live condition were used to determine the slope defining the KIE for each bottle or tube. The errors reported in the text are the standard deviation of the replicate slopes.

\section{Results}

\subsection{SFB5 slurries}

Headspace $\mathrm{C}_{2} \mathrm{H}_{2}$ concentrations decreased monotonically over $\sim 7 \mathrm{~h}$ in bottles containing San Francisco Bay sediment slurries (Fig. 1A). $\mathrm{C}_{2} \mathrm{H}_{2}$ remained constant in the autoclaved control. Stable carbon isotopes of $\mathrm{C}_{2} \mathrm{H}_{2}\left(\delta^{13} \mathrm{C}_{2} \mathrm{H}_{2}\right)$ increased
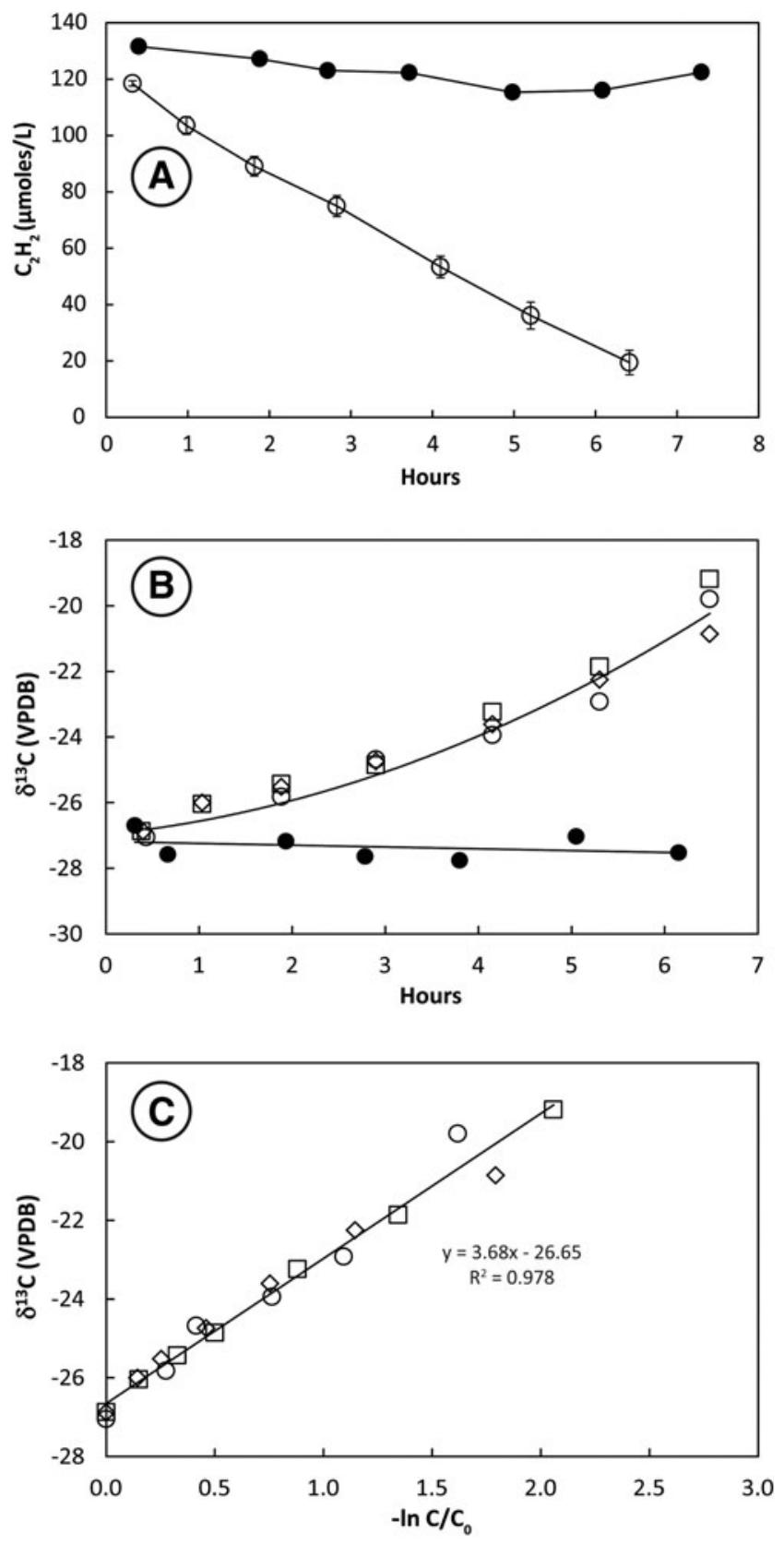

FIG. 1. Uptake of $\mathrm{C}_{2} \mathrm{H}_{2}(\mathbf{A})$, change in $\delta^{13} \mathrm{C}_{2} \mathrm{H}_{2}$ with time (B), and KIE plot (C) for San Francisco Bay sediment slurries SFB5 incubated at $28^{\circ} \mathrm{C}$. Results of a single heat-killed control are shown as closed symbols in (A) and (B). Open symbols in (A) represent the mean of triplicate live bottles. Error bars represent \pm 1 standard deviation. Open symbols in (B) and (C) represent measurements of individual bottles. A linear regression of all analyses along with the slope and $R^{2}$ of the fit is shown in (C) for KIEs measured at $28^{\circ} \mathrm{C}$. 
from initial values around $-27 \%$ in three live bottles but remained constant in the autoclaved control (Fig. 1B). The slope of the plotted line of $\delta^{13} \mathrm{C}_{2} \mathrm{H}_{2}$ against $-\ln \left(\mathrm{C} / \mathrm{C}_{0}\right)$ for three live bottles (Fig. 1C) shows that the KIE for incubations at $28^{\circ} \mathrm{C}$ ranged from $\varepsilon=3.3$ to 4.2 and averaged $3.7 \pm 0.5 \%$.
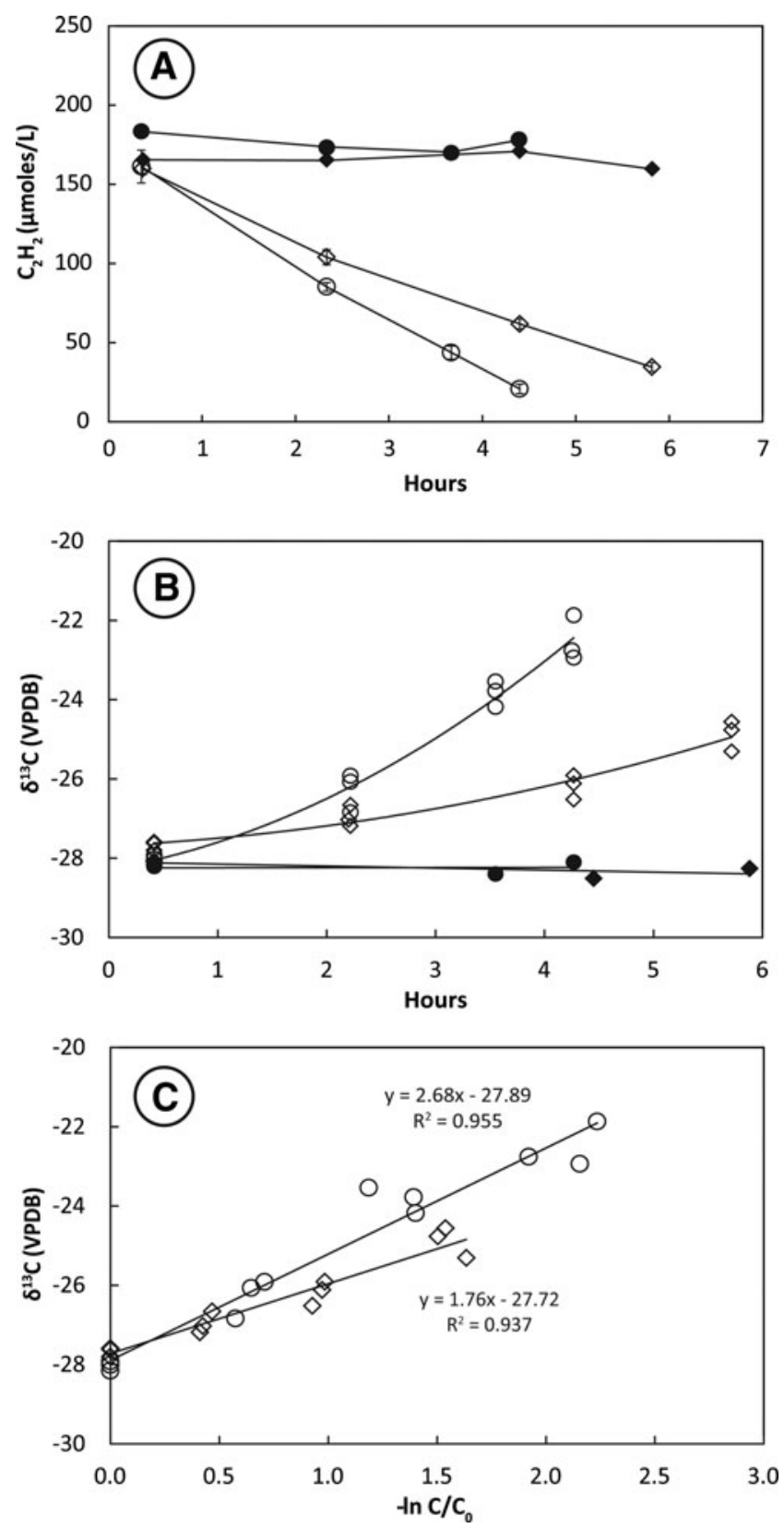

FIG. 2. Uptake of $\mathrm{C}_{2} \mathrm{H}_{2}(\mathbf{A})$, change in $\delta^{13} \mathrm{C}_{2} \mathrm{H}_{2}$ with time (B), and KIE plot (C) for pure-culture SFB93 incubated under growth conditions. Results of single heat-killed control are shown as closed symbols in (A) and (B). Open symbols in (A) represent the mean of triplicate live tubes incubated at $28^{\circ} \mathrm{C}$ (circles) and $14^{\circ} \mathrm{C}$ (diamonds). Error bars represent \pm 1 standard deviation. Open symbols in (B) and (C) represent measurements of individual tubes. A linear regression of all analyses along with the slope and $R^{2}$ of the fit is shown in (C) for KIEs measured at $28^{\circ} \mathrm{C}$ (circles) and $14^{\circ} \mathrm{C}$ (diamonds).

\subsection{SFB93 under growth conditions}

Removal of $\mathrm{C}_{2} \mathrm{H}_{2}$ from the headspace of tubes containing live cultures was nearly linear over the $5-6 \mathrm{~h}$ of uptake (Fig. 2A). Cultures incubated at $28^{\circ} \mathrm{C}$ consumed $\mathrm{C}_{2} \mathrm{H}_{2}$ more rapidly than those incubated at $14^{\circ} \mathrm{C}$. Headspace $\mathrm{C}_{2} \mathrm{H}_{2}$ concentrations remained constant in the autoclaved controls. Stable carbon isotopes of $\mathrm{C}_{2} \mathrm{H}_{2}\left(\delta^{13} \mathrm{C}_{2} \mathrm{H}_{2}\right)$ increased from initial values around $-28 \%$ in tubes containing live cultures (Fig. 2B). This increase was greater in cultures incubated at $28^{\circ} \mathrm{C}$ than in cultures incubated at $14^{\circ} \mathrm{C}$. There was no change in the isotopic composition of $\mathrm{C}_{2} \mathrm{H}_{2}$ in heat-killed controls. The slope of the plotted line of $\delta^{13} \mathrm{C}_{2} \mathrm{H}_{2}$ against $-\ln \left(\mathrm{C} / \mathrm{C}_{0}\right)$ for live tubes (Fig. 2C) shows that the KIE for incubations at $28^{\circ} \mathrm{C}(\varepsilon=2.7 \pm 0.3 \%$ o $)$ was greater than the $\mathrm{KIE}$ for incubations at $14^{\circ} \mathrm{C}(\varepsilon=1.8 \pm 0.3 \%)$.

\subsection{SFB93 under washed cell conditions}

Headspace $\mathrm{C}_{2} \mathrm{H}_{2}$ concentrations decreased rapidly in bottles containing live washed cultures resuspended at high cell density in mineral salts media (Fig. 3A). Cultures incubated at $28^{\circ} \mathrm{C}$ consumed $\mathrm{C}_{2} \mathrm{H}_{2}$ more rapidly than cultures incubated at $14^{\circ} \mathrm{C}$. Headspace $\mathrm{C}_{2} \mathrm{H}_{2}$ concentrations remained constant in the autoclaved controls. Values of $\delta^{13} \mathrm{C}_{2} \mathrm{H}_{2}$ increased faster in cultures incubated at $28^{\circ} \mathrm{C}$ than in cultures incubated at $14^{\circ} \mathrm{C}$ (Fig. 3B). There was no change in the isotopic composition of $\mathrm{C}_{2} \mathrm{H}_{2}$ in heat-killed controls. The slope of the plotted line of $\delta^{13} \mathrm{C}_{2} \mathrm{H}_{2}$ against $-\ln \left(\mathrm{C} / \mathrm{C}_{0}\right)$ for live bottles (Fig. 3C) shows that the KIE for incubations at $28^{\circ} \mathrm{C}(\varepsilon=2.6 \pm 0.2 \%)$ was greater than the $\mathrm{KIE}$ for incubations at $14^{\circ} \mathrm{C}(\varepsilon=1.9 \pm 0.3 \%)$.

\subsection{Searsville Lake methanogenic enrichments (SVM)}

Headspace $\mathrm{C}_{2} \mathrm{H}_{2}$ concentrations decreased slowly in bottles containing mixed culture enrichments derived from sediment transfers. A loss of $90 \mu \mathrm{mol} \mathrm{L}^{-1} \mathrm{C}_{2} \mathrm{H}_{2}$ from the headspace over 3-4 days was accompanied by an increase of $20 \mu \mathrm{mol} \mathrm{L}^{-1} \mathrm{CH}_{4}$ (data not shown). Values of $\delta^{13} \mathrm{C}_{2} \mathrm{H}_{2}$ increased slowly in mixed culture enrichments (Fig. 4B). The slope of the plotted line of $\delta^{13} \mathrm{C}_{2} \mathrm{H}_{2}$ against $-\ln \left(\mathrm{C} / \mathrm{C}_{0}\right)$ for three live bottles (Fig. $4 \mathrm{C}$ ) shows that the KIE for incubations at $28^{\circ} \mathrm{C}$ ranged from $\varepsilon=1.6$ to 2.4 and averaged $1.9 \pm 0.5 \%$.

\subsection{SV7 under growth conditions}

Headspace $\mathrm{C}_{2} \mathrm{H}_{2}$ concentrations decreased very slowly in bottles containing highly enriched mixed culture SV7. Removal of $100 \mu \mathrm{mol} \mathrm{L}{ }^{-1} \mathrm{C}_{2} \mathrm{H}_{2}$ from the headspace of live bottles occurred over 7-10 days (Fig. 5A). During this time, $\delta^{13} \mathrm{C}_{2} \mathrm{H}_{2}$ increased from an initial value of $-28 \%$ to values as high as $-9 \%$ (Fig. 5B). The slope of the plotted line of $\delta^{13} \mathrm{C}_{2} \mathrm{H}_{2}$ against $-\ln \left(\mathrm{C} / \mathrm{C}_{0}\right)$ for six live bottles shows the KIE for incubations at $28^{\circ} \mathrm{C}$ ranged from $\varepsilon=7.9$ to 9.9 and averaged $8.9 \pm 0.8 \%$ o (Fig. $5 \mathrm{C}$ ).

\section{Discussion}

Persistent and uniform KIEs for $\mathrm{C}_{2} \mathrm{H}_{2}$ fermentation were obtained during incubations of San Francisco Bay sediment, enrichments from Searsville Lake sediment, and pure cultures of SFB93 (Pelobacter sp.). KIEs measured by 

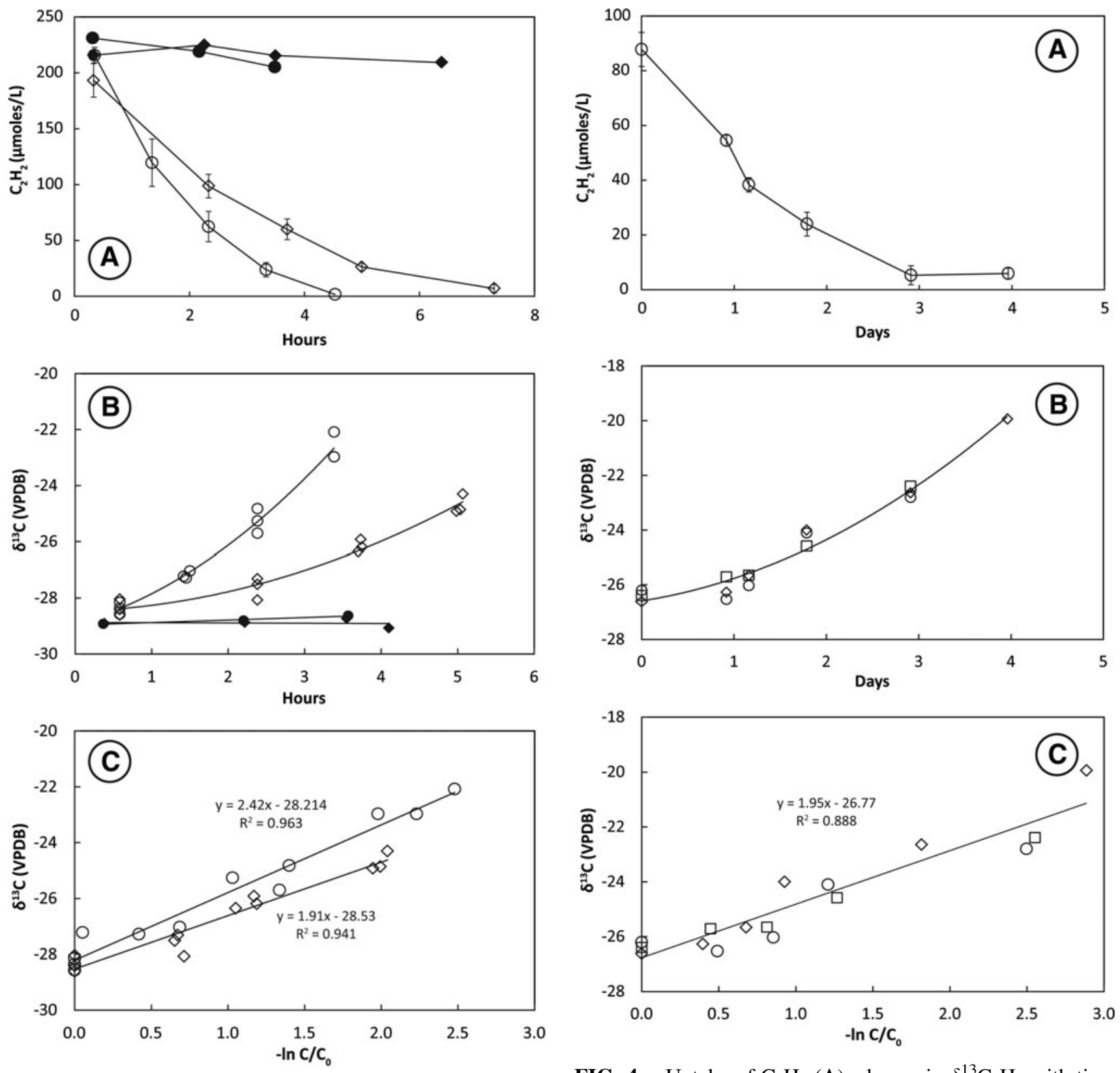

FIG. 3. Uptake of $\mathrm{C}_{2} \mathrm{H}_{2}(\mathbf{A})$, change in $\delta^{13} \mathrm{C}_{2} \mathrm{H}_{2}$ with time (B), and KIE plot (C) for pure-culture SFB93 incubated under washed cell conditions. Results of heat-killed controls are shown as closed symbols in (A) and (B). Open symbols in (A) represent the mean of triplicate live bottles incubated at $28^{\circ} \mathrm{C}$ (circles) and $14^{\circ} \mathrm{C}$ (diamonds). Error bars represent \pm 1 standard deviation. Open symbols in (B) and (C) represent measurements of individual bottles. A linear regression of all analyses along with the slope and $R^{2}$ of the fit is shown in (C) for KIEs measured at $28^{\circ} \mathrm{C}$ (circles) and $14^{\circ} \mathrm{C}$ (diamonds).

primary substrate loss (in this case, $\mathrm{C}_{2} \mathrm{H}_{2}$ loss) reflect all downstream reactions, but KIEs are most influenced by those steps that are rate limiting. Acetylene fermenters such as $P$. acetylenicus carry out sequential exothermic reactions during growth on $\mathrm{C}_{2} \mathrm{H}_{2}$, consisting first of the $\mathrm{AH}$ reaction followed by one involving acetaldehyde dismutase (Schink, 1985):

FIG. 4. Uptake of $\mathrm{C}_{2} \mathrm{H}_{2}(\mathbf{A})$, change in $\delta^{13} \mathrm{C}_{2} \mathrm{H}_{2}$ with time (B), and KIE plot (C) for methanogenic mixed culture SVM incubated under growth conditions. Open circles in (A) represent the mean of triplicate live bottles incubated at $28^{\circ} \mathrm{C}$. Error bars represent \pm 1 standard deviation. Open symbols in (B) and (C) represent measurements of individual bottles. A linear regression of all analyses along with the slope and $R^{2}$ of the fit is shown in (C) for KIEs measured at $28^{\circ} \mathrm{C}$.

$$
\mathrm{C}_{2} \mathrm{H}_{2}+\mathrm{H}_{2} \mathrm{O} \rightarrow \mathrm{CH}_{3} \mathrm{CHO}
$$

$$
2 \mathrm{CH}_{3} \mathrm{CHO}+\mathrm{H}_{2} \mathrm{O} \rightarrow \mathrm{CH}_{3} \mathrm{CH}_{2} \mathrm{OH}+\mathrm{CH}_{3} \mathrm{COO}^{-}+\mathrm{H}^{+}
$$

Additional downstream reactions in sediments and sediment enrichments may utilize the ethanol or acetate formed by Reaction 3 above. These reactions include terminal electron accepting processes such as sulfate reduction and methanogenesis. It is not known which of the above reactions is 

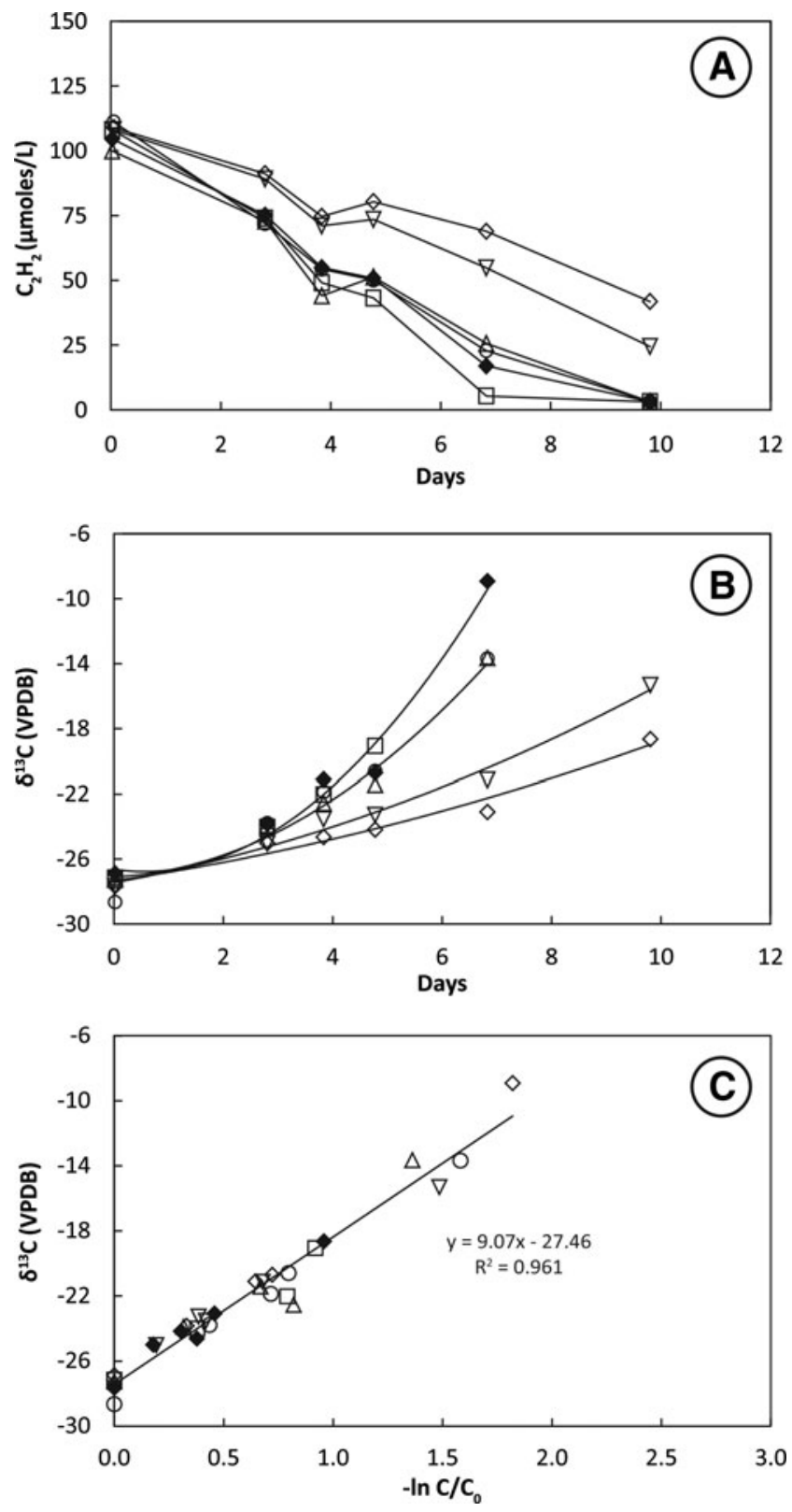

FIG. 5. Uptake of $\mathrm{C}_{2} \mathrm{H}_{2}$ (A), change in $\delta^{13} \mathrm{C}_{2} \mathrm{H}_{2}$ with time (B), and KIE plot (C) for mixed culture SV7 incubated under growth conditions. Symbols represent six individual live bottles incubated at $28^{\circ} \mathrm{C}$. A linear regression of all analyses along with the slope and $R^{2}$ of the fit is shown in (C) for KIEs measured at $28^{\circ} \mathrm{C}$.

primarily responsible for the fractionation of carbon isotopes observed. In any case, the fractionation we measured $(\mathrm{KIE} \sim 3 \%$ ) is neither as large as the KIEs determined for anaerobic or aerobic oxidation of methane (10-30\%; Alperin et al., 1988; Whiticar, 1999; Templeton et al., 2006) nor as large as the very high KIEs reported for microbial oxidation of methyl halides $(70 \%$; Miller et al., 2001). However, the KIEs observed for oxidation of other $\mathrm{C}_{2}$ hydrocarbons [ethylene $=3 \%$ (Bloom et al., 2000) and ethane $=8 \%$ (Kinnaman et al., 2007)] were similar to those values reported here for $\mathrm{C}_{2} \mathrm{H}_{2}$ fermentation.
Consistent KIEs of 3-4\% were achieved by San Francisco Bay sediment slurries (SFB5) during $\mathrm{C}_{2} \mathrm{H}_{2}$ fermentation (Fig. 1). Repeated experiments with these sediments produced similar KIEs (data not shown). These results were expected, given the observations reported above for other $\mathrm{C}_{2}$ metabolisms. Similar KIEs were observed during $\mathrm{C}_{2} \mathrm{H}_{2}$ fermentation by the pure culture SFB93 (Figs. 2 and 3 ). Measurements of KIEs in both growing cultures and washed cell suspensions showed identical fractionation patterns with regard to absolute values and temperature effects. This implies that incorporation of carbon into cell biomass during growth is not an influential step in controlling KIEs and further suggests that either growing or washed cell cultures may be employed to evaluate KIEs. Cultures incubated at $28^{\circ} \mathrm{C}$ yielded significantly higher KIEs $(p<0.01)$ than cultures incubated at $14^{\circ} \mathrm{C}$; however, these differences amounted to less than $1 \%$. It may be that higher KIEs at warmer temperature reflect higher rates of $\mathrm{C}_{2} \mathrm{H}_{2}$ uptake. The preferred growth temperature for $P$. acetylenicus is $28^{\circ} \mathrm{C}$ (Schink, 1985), and the optimal temperature for $\mathrm{AH}$ activity is $50^{\circ} \mathrm{C}$. (Rosner and Schink, 1995). Even so, KIEs do not always reflect differences in substrate utilization rate (Miller et al., 2001), and when they do, higher rates often correlate with lower KIEs (Templeton et al., 2006), in contrast to our observations.

Fermentation of $\mathrm{C}_{2} \mathrm{H}_{2}$ resulted in similar KIEs for Searsville Lake methanogenic enrichment SVM (Fig. 4) as those obtained for SFB5 and SFB93 (Figs. 1-3). At a fine scale, KIEs of incubations conducted at $28^{\circ} \mathrm{C}$ were somewhat lower for SVM $(\varepsilon=1.9)$ than for SFB5 or SFB93 incubated at $28^{\circ} \mathrm{C}(\varepsilon=3.7$ and 2.7 , respectively). Searsville Lake enrichments were mixtures consisting of many different microorganisms including sulfate reducers when cultivated in the presence of sulfate (Miller et al., 2013). In this regard they are more akin to sediment slurries than to pure cultures of $\mathrm{C}_{2} \mathrm{H}_{2}$ fermenters (Table 1). The composition of the microbial community in SVM was not determined; however, we hypothesize that pelobacter-like organisms containing AH may be present and could account for the similar KIE to SFB5 and SFB93.

Earlier attempts at purification of $\mathrm{C}_{2} \mathrm{H}_{2}$ fermenters from the milieu of Searsville Lake sediments resulted in the stable mixed culture strain SV7 (Miller et al., 2013). One line of this strain (YE5) was capable of $\mathrm{C}_{2} \mathrm{H}_{2}$ fermentation but lacked the $\mathrm{AH}$ gene as determined by gene probing with degenerate primers (Miller et al., 2013). This was the SV7 culture evaluated here for KIE determination (Table 1; Fig. 5). The KIE obtained from six replicate bottles $(\varepsilon=8.9 \pm 0.8 \%$ o $)$ was significantly $(P<0.01)$ greater than those observed for SFB5, SFB93, or SVM. This different KIE suggests that $\mathrm{C}_{2} \mathrm{H}_{2}$ degradation may proceed by an alternative pathway in SV7. It is possible that a reaction involving carbon occurs in the fermentation pathway of SV7 that does not occur in SVM, SFB5, or SFB93. If such a reaction discriminated in favor of ${ }^{12} \mathrm{C}$, it would contribute to the total isotope effect observed. Incubations with SV7 were conducted as growth experiments; hence, it may be that this greater fractionation reflects a different pathway of incorporation of carbon into cell biomass. However, we favor the following mechanism: Whereas both SFB93 and SV7 produced acetate as a stable end product with minor amounts of intermediate products acetaldehyde and ethanol, SV7 in addition produced formate as a stable end 
product (Miller et al., 2013). We speculate that an unknown reaction leading to production of formate could result in additional isotopic fractionation observed in SV7. Further examination of this reaction pathway is needed to assess the veracity of this speculation. At this time, we do not know which of the six or so dominant organisms identified in SV7 via $16 \mathrm{~S}$ rRNA sequence similarity assessment (Miller et al., 2013) is conducting this putative step. Planned stable isotope probing of SV7 using ${ }^{13} \mathrm{C}_{2} \mathrm{H}_{2}$ will indicate the most active participant(s) in the degradation of $\mathrm{C}_{2} \mathrm{H}_{2}$ (Dumont and Murrell, 2005), which may aid in delineation of this unknown reaction.

In conclusion, we successfully demonstrated that regular and persistent fractionation of stable carbon isotopes occurs during $\mathrm{C}_{2} \mathrm{H}_{2}$ fermentation by live sediments, sediment enrichments, and pure cultures. This is the required first step in distinguishing biological from abiotic degradation of $\mathrm{C}_{2} \mathrm{H}_{2}$. However, we have examined only the overall fractionation (KIE) associated with degradation of the primary substrate $\mathrm{C}_{2} \mathrm{H}_{2}$. In practice, synchronous measurements of $\delta^{13} \mathrm{C}$ in reactants and products for individual steps in the reaction pathway can provide additional information to the conclusions derived from measurements of $\delta^{13} \mathrm{C}$ of reactants alone. This approach has proven successful in studies of variable pathways of degradation of subsurface organic contaminants such as chlorinated ethenes (Hunkeler et al., 2002; Elsner et al., 2005, 2008; Hofstetter et al., 2008). We propose applying this strategy to distinguish biological from abiotic $\mathrm{C}_{2} \mathrm{H}_{2}$ degradation in extraterrestrial environs provided each pathway results in a different KIE. For example, the Cassini mission collected material and spectroscopic data that suggest the water-rich plume emanating from Enceladus represents the composition of the aqueous environment below the moon's icy crust (Waite et al., 2006; Matson et al., 2007; Hansen et al., 2011). If biological processes operating in the subsurface consume $\mathrm{C}_{2} \mathrm{H}_{2}$ and produce acetaldehyde, ethanol, and acetate, then measurement of $\delta^{13} \mathrm{C}$ of $\mathrm{C}_{2} \mathrm{H}_{2}$ and its degradation products in the plume should yield evidence of life below the surface of Enceladus. Measurement of $\delta^{13} \mathrm{C}_{2} \mathrm{H}_{2}$ alone would not provide unambiguous evidence of a biological process without conducting incubations of subsurface liquids containing $\mathrm{C}_{2} \mathrm{H}_{2}$. However, measurement of large differences between $\delta^{13}$ of $\mathrm{C}_{2} \mathrm{H}_{2}$ and acetaldehyde, or any other carbonaceous product (e.g., ethanol, acetate, or formate) in the plume would suggest the possibility of biological fractionation. These measurements require additional analytical capabilities to those on board the Cassini spacecraft.

\section{Acknowledgments}

We thank Steve Silva and Sara Peek of the Kendall Isotope Lab for help with method development for KIE measurements. We are indebted to Jodi Blum, Shelley McCann, and Stacy Bennett for assistance in the laboratory. Mark Waldrop and Christopher H. Conaway reviewed an earlier version of this manuscript. Support from NASA Astrobiology/Exobiology and USGS NRP is greatly appreciated.

\section{Author Disclosure Statement}

No competing financial interests exist.

\section{References}

Alperin, M.J., Reeburgh, W.S., and Whiticar, M.J. (1988) Carbon and hydrogen isotope fractionation resulting from anaerobic methane oxidation. Global Biogeochem Cycles 2:279-288.

Andrea, M.O. and Merlet, P. (2001) Emission of trace gases and aerosols from biomass burning. Global Biogeochem Cycles 15:955-966.

Belay, N. and Daniels, L. (1987) Production of ethane, ethylene, and acetylene from halogenated hydrocarbons by methanogenic bacteria. Appl Environ Microbiol 53:1604-1610.

Bill, M., Schuth, C., Barth, J.A.C., and Kalin, R.M. (2001) Carbon isotope fractionation during abiotic reductive dehalogenation of trichloroethene (TCE). Chemosphere 44: 1281-1286.

Bill, M., Miller, L.G., and Goldstein, A.H. (2002) Carbon isotope fractionation of methyl bromide during agricultural soil fumigations. Biogeochemistry 60:181-190.

Bloom, Y., Aravena, R., Hunkeler, D., Edwards, E., and Frapa, S.K. (2000) Carbon isotope fractionation during microbial dechlorination of trichloroethene, cis-1,2 dichloroethene, and vinyl chloride: implication for assessment of natural attenuation. Environ Sci Technol 34:2768-2772.

Breen, J.E. and Glass, G.P. (1971) The reaction of the hydroxyl radical with acetylene. International Journal of Chemical Kinetics 3:145-153.

Brooke, T.Y., Tokunaga, A.T., Weaver, H.A., Crovisier, J., Bockelée-Morvan, D., and Crisp, D. (1996) Detection of acetylene in the infrared spectrum of comet Hyakutake. Nature 383:606-608.

Cantrell, C.A., Shetter, R.E., McDaniel, A.H., Calvert, J.G., Davidson, J.A., Lowe, D.C., Tyler, S.C., Cicerone, R.J., and Greenberg, J.P. (1990) Carbon kinetic isotope effect in the oxidation of methane by the hydroxyl radical. J Geophys Res Atmos 95:22455-22462.

Chyba, C.F., Thomas, P.J., Brookshaw, L., and Sagan, C. (1990) Cometary delivery of organic molecules to the early Earth. Science 249:366-373.

Cordier, D., Mousis, O., Lunine, J.I., Lavvas, P., and Vuitton, V. (2009) An estimate of the chemical composition of Titan's lakes. Astrophys J 707:L128-L131.

Culbertson, C.W., Zehnder, A.J.B., and Oremland, R.S. (1981) Anaerobic oxidation of acetylene by estuarine sediments and enrichment cultures. Appl Environ Microbiol 41:396-403.

Culbertson, C.W., Strohmaier, F.E., and Oremland, R.S. (1988) Acetylene as a substrate in the development of primordial bacterial communities. Orig Life Evol Biosph 18:397-407.

de Bont, J.A.M. and Peck, M.W. (1980) Metabolism of acetylene by Rhodococcus A1. Arch Microbiol 127:99-104.

Dumont, M.G. and Murrell, J.C. (2005) Stable isotope probinglinking microbial identity to function. Nat Rev Microbiol 3: 499-504.

Elsner, M., Zwank, L., Hunkeler, D., and Schwarzenbach, R.P. (2005) A new concept linking observable stable isotope fractionation to transformation pathways of organic pollutants. Environ Sci Technol 39:6896-6916.

Elsner, M., Chartrand, M., Vanstone, N., Couloume, G.L., and Sherwood Lollar, B. (2008) Identifying abiotic chlorinated ethene degradation: characteristic isotope patterns in reaction products with nanoscale zero-valent iron. Environ Sci Technol 42:5963-5970.

Hansen, C.J., Shemansky, D.E., Esposito, L.W., Sterart, A.I.F., Lewis, B.R., Colwell, J.E., Hendrix, A.R., West, R.A., Waite, J.H., Jr., Teolis, B., and Magee, B.A. (2011) The composition 
and structure of the Enceladus plume. Geophys Res Lett 38:L11202-L11206.

Hart, E.J., Fisher, C.-H., and Henglein, A. (1990) Pyrolosis of acetylene in sonolytic bubbles in aqueous solution. J Phys Chem 94:284-290.

Hobbie, J.E., Daley, R.L., and Jaspar, S. (1977) Use of Nuclepore filters for counting bacteria for fluorescence microscopy. Appl Environ Microbiol 33:1225-1228.

Hofstetter, T.B., Schwarzenbach, R.P., and Bernasconi, S.M. (2008) Assessing transformation processes of organic compounds using stable isotope fractionation. Environ Sci Technol 42:7737-7743.

Hunkeler, D., Aravena, R., and Cox, E. (2002) Carbon isotopes as a tool to evaluate the origin and fate of vinyl chloride: laboratory experiments and modeling of isotope evolution. Environ Sci Technol 36:3378-3384.

Kalin, R.M., Hamilton, J.T.G., Harper, D.B., Miller, L.G., Lamb, C., Kennedy, J.T., Downey, A., McCauley, S., and Goldstein, A.H. (2001) Continuous flow stable isotope methods for study of $\delta^{13} \mathrm{C}$ fractionation during halomethane production and degradation. Rapid Commun Mass Spectrom 15:357-363.

Kanner, D. and Bartha, R. (1979) Growth of Nocardia rhodochrous on acetylene gas. J Bacteriol 139:225-230.

Kasting, J.F. (2005) Methane and climate during the Precambrian era. Precambrian Res 137:119-129.

Kasting, J.F., Zahnle, K.J., and Walker, J.C.G. (1983) Photochemistry of methane in the Earth's early atmosphere. Precambrian Res 20:121-148.

Kinnaman, F.S., Valentine, D.L., and Tyler, S.C. (2007) Carbon and hydrogen isotope fractionation associated with the aerobic microbial oxidation of methane, ethane, propane, and butane. Geochim Cosmochim Acta 71:271-283.

Liang, X., Dong, Y., Kuder, T., Krumholz, L.R., and Butler, E.C. (2007) Distinguishing abiotic and biotic transformation of tetrachloroethylene and trichloroethylene by stable carbon isotope fractionation. Environ Sci Technol 41:7094-7100.

Macy, W., Jr. (1980) Mixing ratios of methane, ethane, and acetylene in Neptune's stratosphere. Icarus 41:153-158.

Matson, D.L., Castillo, J.C., Lunine, J., and Johnson, T.V. (2007) Enceladus' plume: compositional evidence for a hot interior. Icarus 187:569-573.

McKay, C.P. and Smith, H.D. (2005) Possibilities for methanogenic life in liquid methane on the surface of Titan. Icarus 178:274-276.

McKay, C.P., Khare, B.N., Amin, R., Klasson, M., and Kral, T.A. (2012) Possible sources for methane and $\mathrm{C}_{2}-\mathrm{C}_{5}$ organics in the plume of Enceladus. Planet Space Sci 71:73-79.

Meckenstock, R.U., Krieger, R., Ensign, S., Kroneck, P.M.H., and Schink, B. (1999) Acetylene hydratase of Pelobacter acetylenicus: molecular and spectroscopic properties of the tungsten iron-sulfur enzyme. Eur J Biochem 264:176-182.

Meckenstock, R.U., Morasch, B., Griebler, C., and Richnow, H.H. (2004) Stable isotope fractionation analysis as a tool to monitor biodegradation in contaminated aquifers. $J$ Contam Hydrol 75:215-255.

Miller, L.G., Connell, T.L., Guidetti, J.R., and Oremland, R.S. (1997) Bacterial oxidation of methyl bromide in fumigated agricultural soils. Appl Environ Microbiol 63:4346-4354.

Miller, L.G., Kalin, R.M., McCauley, S.E., Hamilton, J.T.G., Harper, D.B., Millet, D.B., Oremland, R.S., and Goldstein, A.H. (2001) Large carbon isotope fractionation associated with oxidation of methyl halides by methylotrophic bacteria. Proc Natl Acad Sci USA 98:5833-5837.
Miller, L.G., Warner, K.L., Baesman, S.M., Oremland, R.S., McDonald, I.R., Radajewski, S., and Murrell, J.C. (2004) Degradation of methyl bromide and methyl chloride in soil microcosms: use of stable $\mathrm{C}$ isotope fractionation and stable isotope probing to identify reactions and the responsible microorganisms. Geochim Cosmochim Acta 68:3271-3283.

Miller, L.G., Baesman, S.M., Kirshtein, J., Voytek, M.A., and Oremland, R.S. (2013) A biogeochemical and genetic survey of acetylene fermentation by environmental samples and bacterial isolates. Geomicrobiol J 30:501-516.

Mumma, M.J., DiSanti, M.A., Magee-Sauer, K., Bonev, B.P., Villanueva, G.L., Kawakita, H., Dello Russo, N., Gibb, E.L., Blake, G.A., Lyke, J.E., Campbell, R.D, Aycock, J., Conrad, A., and Hill, G.M. (2005) Parent volatiles in Comet 9P/ Tempel 1: before and after impact. Science 310:270-274.

Noll, K.S., Knacke, R.F., Tokunaga, A.T., Lacy, J.H., Beck, S., and Serabyn, E. (1986) The abundance of ethane and acetylene in the atmospheres of Jupiter and Saturn. Icarus 65: 257-263.

Oremland, R.S. and Voytek, M.A. (2008) Acetylene as fast food: implications for development of life on anoxic primordial Earth and in the outer Solar System. Astrobiology $8: 45-58$

Oremland, R.S., Miller, L.G., Culbertson, C.W., Connell, T.L., and Jahnke, L. (1994) Degradation of methyl bromide by methanotrophic bacteria in cell suspensions and soils. Appl Environ Microbiol 60:3640-3646.

Pohlman, J.W., Kaneko, M., Veher, V.B., Coffin, R.B., and Whiticar, M. (2009) Methane sources and production in the northern Cascadia margin gas hydrate system. Earth Planet Sci Lett 287:504-512.

Postberg, F., Schmidt, J., Hillier, J., Kempf, S., and Srama, R. (2011) A salt-water reservoir as the source of a compositionally stratified plume on Enceladus. Nature 474:620-622.

Reppe, W., Kutepow, N.V., and Magin, A. (1969) Cyclization of acetylenic compounds. Angwandte Chemie 8:727-733.

Rosenfeld, W.E. and Silverman, S.R. (1959) Carbon isotopic fractionation in bacterial production of methane. Science 130:1658-1659.

Rosner, B.M. and Schink, B. (1995) Purification and characterization of acetylene hydratase of Pelobacter acetylenicus, a tungsten iron-sulfur protein. J Bacteriol 177:5767-5773.

Rosner, B.M., Rainey, F.A., Kroppenstedt, R.M., and Schink, B. (1997) Acetylene degradation by new isolates of aerobic bacteria and comparison of acetylene hydratase enzymes. FEMS Microbiol Lett 148:175-180.

Rust, F. and Stephens, C.M. (1980) Carbon kinetic isotope effect in the oxidation of methane by hydroxyl. International Journal of Chemical Kinetics 12:371-377.

Schink, B. (1985) Fermentation of acetylene by an obligate anaerobe, Pelobacter acetylenicus sp. nov. Arch Microbiol 142:295-301.

Schoell, M. (1980) The hydrogen and carbon isotopic composition of methane from natural gases of various origins. Geochim Cosmochim Acta 44:649-661.

Schoell, M. (1988) Multiple origins of methane in the Earth. Chem Geol 71:1-10.

Schulze-Makuch, D. and Grinspoon, D.H. (2005) Biologically enhanced energy and carbon cycling on Titan? Astrobiology $5: 560-567$.

Seiffert, G.B., Ullmann, G.M., Messerschmidt, A., Schink, B., Kroneck, P.M.H., and Einsle, O. (2007) Structure of the nonredox-active tungsten/[4Fe:4S] enzyme acetylene hydratase. Proc Natl Acad Sci USA 104:3073-3077. 
Shemansky, D.E., Stewart, A.I.F., West, R.A., Esposito, L.W., Hallet, J.T., and Liu, X. (2005) The Cassini UVIS stellar probe of the Titan atmosphere. Science 308:978-982.

Sherwood Lollar, B., Lacrampe-Couloume, G., Voglesonger, K., Onstatt, T.C., Pratt, L.M., and Slater, G.F. (2008) Isotopic signatures of $\mathrm{CH}_{4}$ and higher hydrocarbon gases from Precambrian Shield sites: a model for abiogenic polymerization of hydrocarbons. Geochim Cosmochim Acta 72:4778-4795.

Slater, G.F., Sherwood Lollar, B., Allen King, R., and O'Hannesin, S. (2002) Isotopic fractionation during reductive dehalogenation of trichlorethene by zero-valent iron: influence of surface treatment. Chemosphere 49:587-596.

Studt, F., Abild-Pedersen, F., Bligaard, T., Sorensen, R.Z., Christensen, C.H., and Norskov, J.K. (2008) Identification of non-precious metal alloy catalysts for selective hydrogenation of acetylene. Science 320:1320-1322.

Templeton, A.S., Chu, K.-H., Alvarez-Cohen, L., and Conrad, M. (2006) Variable carbon isotope fractionation expressed by aerobic $\mathrm{CH}_{4}$-oxidizing bacteria. Geochim Cosmochim Acta 70:1739-1752.

tenBrink, F., Schink, B., and Kroneck, P.M.H. (2011) Exploring the active site of the tungsten, iron-sulfur enzyme acetylene hydratase. J Bacteriol 193:1229-1236.

Waite, J.H., Jr., Combi, M.R., Ip, W.-H., Cravens, T.E., McNutt, R.L., Jr., Kasprzak, W., Yelle, R., Luhmann, J., Niemann, H., Gell, D., Magee, B., Fletcher, G., Lunine, J., and Tseng, W.-L. (2006) Cassini ion and neutral mass spectrometer: Enceladus plume composition and structure. Science 311:1419-1422.

Waite, J.H., Jr., Young, D.T., Cravens, T.E., Coates, A.J., Crary, F.J., Magee, B., and Westlake, J. (2007) The process of tholin formation in Titan's upper atmosphere. Science 316:870-875.

Waite, J.H., Jr., Lewis, W.S., Magee, B.A., Lunine, J.I., McKinnon, W.B., Glein, C.R., Mousis, O., Young, D.T., Brockwell, T., Westlake, J., Nguyen, M.-J., Teolis, B.D., Niemann, H.B., McNutt, R.L., Perry, M., and Ip, W.-H. (2009) Liquid water on Enceladus from observations of ammonia and ${ }^{40} \mathrm{Ar}$ in the plume. Nature 460:487-490.
Whiticar, M.J. (1999) Carbon and hydrogen isotope systematics of bacterial formation and oxidation of methane. Chem Geol 161:291-314.

Whiticar, M.J., Faber, E., and Schoell, M. (1986) Biogenic methane formation in marine and freshwater environments: $\mathrm{CO}_{2}$ reduction vs. acetate fermentation-isotope evidence. Geochim Cosmochim Acta 50:693-709.

Widdel, F., Kohring, G.-W., and Mayer, F. (1983) Studies on the dissimilatory sulfate-reducing bacteria that decompose fatty acids. 3. Characterization of the filamentous gliding Desulfonema limnicola, gen. nov., sp. nov., and Desulfonema magnum, sp. nov. Arch Microbiol 134:286-294.

Zahnle, K.J. (1986) Photochemistry of methane and the formation of hydrocyanic acid ( $\mathrm{HCN})$ in the Earth's early atmosphere. J Geophys Res 91:2819-2834.

Address correspondence to: Laurence G. Miller U.S. Geological Survey 345 Middlefield $R d$. Menlo Park, CA 94025

E-mail: 1gmiller@usgs.gov

Submitted 20 May 2015 Accepted 10 September 2015

\begin{tabular}{|c|}
\hline Abbreviations Used \\
\hline $\mathrm{ABW}=$ artificial mineral salts media \\
\hline $\mathrm{AH}=$ acetylene hydratase enzyme \\
\hline EA-IRMS $=\begin{array}{c}\text { elemental analyzer-isotope ratio mass } \\
\text { spectrometry }\end{array}$ \\
\hline GC-C-IRMS $=$ isotope-ratio-monitoring gas \\
\hline chromatography-combustion- \\
\hline mass spectrometry \\
\hline KIEs $=$ kinetic isotope effects \\
\hline
\end{tabular}

